\title{
THE CLINTON ADMINISTRATION AND WAR POWERS
}

\author{
LORI FISLER DAMROSCH*
}

I

\section{INTRODUCTION: WAR POWERS IN CROSSNATIONAL PERSPECTIVE}

The strongest of all governmental powers is the power to engage in war; and the strongest challenge for constitutionalism is to bring the war power of the state under meaningful control. The 1787 Constitution allocated some military powers to the Congress and others to the President as part of the scheme of constitutional checks and balances. To this day, however, the distribution of authority between the branches remains contested and uncertain.

The Clinton Administration has had substantial opportunity to contribute to the evolution of constitutional practice concerning war powers, by virtue of numerous occasions of combat deployments, cruise missile strikes, and other forms of military engagement since January 1993. In broad outline, the constitutional practice of the Clinton Administration concerning war powers is similar to that of previous administrations in the sense that sweeping claims of executive authority have been tempered through pragmatic political accommodation. The legal opinions issued to explain the constitutional and statutory rationales for executive military initiatives embody some subtle differences from those of other administrations. This article compares the record of the Clinton Administration with those of its predecessors, after first briefly locating U.S. war powers practice in the context of crossnational comparisons.

The subject of the Clinton Administration and war powers can be addressed from a crossnational perspective, along the lines of the comparative constitutional research on war powers I have been pursuing in other writing. ${ }^{1}$ In relation to the military intervention in Kosovo, for example, how did President Clinton's exercise of executive power compare to the authority of the heads of state or heads of government in the other member states of the North Atlantic Treaty Organization ("NATO") that participated in the operation? Were other chief executives constitutionally authorized to commit their forces to a military campaign without reference to their national parliaments, as President Clinton

Copyright (C) 2000 by Lori Fisler Damrosch

This essay is also available at http://www.law.duke.edu/journals/63LCPDamrosch.

* Henry L. Moses Professor of Law and International Organization, Columbia University.

1. For aspects of this work in progress, see, e.g., Lori Fisler Damrosch, Use of Force and Constitutionalism, 36 Colum. J. Transnat'L L. 449 (1997); Lori Fisler Damrosch, Constitutional Control Over War Powers: A Common Core of Accountability in Democratic Societies? 50 U. MIAMI L. REV. 181 (1995). 
effectively did, or are such decisions shared with parliament in the respective constitutional systems?

Crossnational comparisons show variations in the degree to which national parliaments participated in determining the nature of a given state's commitment to the NATO engagement in Kosovo. President Clinton was not the only NATO leader who initiated his country's participation in the Kosovo operation without obtaining explicit authorization from the legislative branch. In the parliamentary system of the United Kingdom, Prime Minister Tony Blair may assume support from the House of Commons without necessarily putting the matter to a formal vote. . In France's mixed system, President Jacques Chirac operates under Gaullist premises that military decisions belong to the presidential domaine reservé with little scrutiny from the Assemblée Nationale. ${ }^{3}$ In other countries, however, parliamentary control is considered a fundamental constraint on executive war-making powers. Germany's postwar constitution broke with the past by renouncing war, but participation in collective defense or collective security organizations is constitutionally permitted, subject to parliamentary approval. ${ }^{4}$ Notably, as required by a decision of the German Federal Constitutional Court at an earlier stage of the Yugoslav conflict, ${ }^{5}$ the Bundestag had to act affirmatively to approve German involvement in the Kosovo campaign. ${ }^{6}$

Polities in transition have looked to diverse constitutional models in developing their own approaches to executive-legislative relations with respect to war powers. The newest NATO members and NATO aspirants had their first tests of constitutional control of war powers in the post-cold war era with the Kosovo crisis. Hungary, a front-line state for this conflict, which borders on Yugoslavia and has close ties to ethnic Hungarians in the Vojvodina region of Serbia, submitted certain critical decisions for the affirmative authorization of the national parliament. ${ }^{7}$ Bulgaria and Romania, not yet NATO members but

2. Prime Minister Tony Blair addressed the House of Commons on the eve of initiation of combat and received a pledge of support from the leader of the opposition, William Hague. Hansard, Mar. 23, 1999, cols. 161, 163.

3. For a discussion of the external powers of the Président de la République in relation to republican traditions, see ELISABETH ZOLLER, DROIT DES RELATIONS EXTÉRIEURES 80-83, 234-236 (1990).

4. For a discussion of the renunciation of aggressive war in the German Constitution and related treatment of collective defense and security, see DONALD KOMMERS, THE CONSTITUTIONAL JURISPRUDENCE OF THE FEDERAL REPUBLIC OF GERMANY 157-64 (2d ed. 1997).

5. Military Deployment case, 90 BVerfGE 286 (1994), discussed in KOMMERS, supra note 4, at 162-64. For excerpts in English translation, see 106 INT'L L. REPS. 318-52.

6. In extraordinary session on October 16, 1998, the Bundestag voted in favor of participation by the federal armed forces in the NATO intervention in Kosovo. Votes were also held on November 19, 1998 to approve participation in a NATO extraction force in Macedonia and on February 25, 1999 for use of troops in a post-crisis stabilization force in Kosovo. See Simon Duke et al., The Major European Allies: France, Germany and the United Kingdom, in Kosovo AND THE CHALLENGE OF HUMANITARIAN INTERVENTION (Albrecht Schnabel \& Ramesh Thakur eds., forthcoming 2000).

7. See Péter Tálas \& László Valki, The New Entrants: Hungary, Poland, and the Czech Republic, in Kosovo AND THE CHALLENGE OF HUMANITARIAN INTERVENTION, supra note 6 (noting that the Hungarian parliament gave approval in October 1998 for use of Hungarian airspace by NATO aircraft; 
eager to prove themselves to be suitable partners, had parliamentary votes to approve opening their airspace to NATO planes. ${ }^{8}$

The remainder of this article focuses on comparisons between the Clinton Administration and its predecessors: Does President Clinton's approach to war powers and other foreign policy problems cohere with that of previous Presidents, or has the present administration forged a new approach in these domains? This general question also addresses the theme of Dawn Johnsen's paper: ${ }^{9}$ To what extent has the executive branch under Clinton declined to comply with congressional enactments regarding war powers on the basis of an executive position that the law in question is unconstitutional?

II

\section{PREVIOUS AdMinistrations AND THE WAR POWERs DEBATE}

With minor variations in emphasis, basically all administrations since the enactment of the War Powers Resolution ${ }^{10}$ in 1973 have maintained that Congress cannot constitutionally restrict the President's commander-in-chief powers grounded in Article II of the Constitution. Presidents have insisted on exercising the powers of their office compatibly with their own sense of Article II's prerogatives. They have been loath to acknowledge the congressional position embodied in the War Powers Resolution that the "collective judgment of both the Congress and the President" is constitutionally required to introduce U.S. armed forces into hostilities. ${ }^{11}$

President Nixon vetoed the War Powers Resolution on constitutional grounds, ${ }^{12}$ but his veto was overridden, and the Resolution became law. ${ }^{13}$ Thus, in Professor Johnsen's terms, President Nixon set a precedent for future nonapplication of the War Powers Resolution on the basis of an executive position concerning its unconstitutionality. ${ }^{14}$

parliament met in extraordinary session March 24, 1999 to approve unrestricted use of airspace and facilities; parliament later debated term "unrestricted" as situation evolved).

8. See Andrew J. Pierre, De-Balkanizing the Balkans: Security and Stability in Southeastern Europe, U.S. INST. PEACE SPECIAL REPORT 3, 5 (Sept. 20, 1999) (noting that the Bulgarian parliament reluctantly approved permission for air rights but not ground transit, and noting that the Romanian parliament voted air rights, with the principal opposition party abstaining).

9. See Dawn Johnsen, Presidential Enforcement of Constitutionally Objectionable Statues, 63 LAW \& CONTEMP. PROBS. 7 (Winter/Spring 2000).

10. Pub. L. No. 93-148, 87 Stat. 555 (1973) (codified at 50 U.S.C. $\$ \$ 1541-1548$ (1998)).

11. 50 U.S.C. $\$ 1541$ (a) (1998).

12. See 9 WeEkly COMP. Pres. Docs. 1285-86 (Oct. 24, 1973). President Nixon's constitutional objections included the concurrent veto feature of $\S 5(\mathrm{c})$, as well as the automatic cut-off of certain authorities after sixty days in the absence of a congressional extension: "I believe that both these provisions are unconstitutional. The only way in which the constitutional powers of a branch of the Government can be altered is by amending the Constitution - and any attempt to make such alterations by legislation alone is clearly without force." Id.

13. To underscore that a joint resolution has the full authority of an enacted statute, some prefer that the War Powers Resolution be known as the "War Powers Act." See JOHN HART Ely, WAR AND RESPONSIBILITY: CONSTITUTIONAL LESSONS OF VIETNAM AND ITS AFTERMATH 115 (1994).

14. See Johnsen, supra note 9, 27-28. 
President Ford complied with the reporting requirements of the War Powers Resolution in relation to evacuations from Danang, Phnom Penh, and Saigon, and the retaking of the SS Mayaguez..$^{15}$ Nonetheless, he maintained the position of principle that the War Powers Resolution could not impair the President's constitutionally-based powers. ${ }^{16}$ When reporting to Congress as the War Powers Resolution provides, ${ }^{17}$ neither Ford nor his successors ever conceded that any legally operational significance would attach to a report submitted "consistent with the War Powers Resolution." ${ }^{18}$ In other words, no President has ever acknowledged the Resolution's timetable of sixty or ninety days for withdrawal of troops (unless Congress were to authorize their participation in hostilities) ${ }^{19}$ to be running. ${ }^{20}$

President Carter had fewer warlike incidents during his tenure than either his predecessors or his successors: Only the failed Iran hostage rescue raid brought the reporting requirements of the War Powers Resolution into play during the Carter Administration. ${ }^{21}$ President Carter's counsel, Lloyd Cutler, wrote a legal opinion stating that consultation with Congress was not required in advance of that mission because the War Powers Resolution by its terms merely provides for consultation "in every possible instance." 22 Thus, the implication is that Congress must have contemplated instances-of which the Iran raid could be exemplary - in which consultation would be impossible. Furthermore, Cutler argued, the Resolution should be construed to avoid impinging on the President's inherent constitutional power to conduct a rescue operation that is dependent on total surprise.

15. For the reports submitted to Congress, see 121 CONG. REC. 9079 (Danang), 10065 (Phnom Penh), 12803-04 (Saigon), and 14452 (Mayaguez), reprinted in W. TAYLOR REVELEY III, WAR POWERS OF THE PRESIDENT AND CONGRESS: WHO HOLDS THE ARROWS AND OLIVE BRANCH? 297303 (1981).

16. Ford's criticisms of the War Powers Resolution, on constitutional and policy grounds, were most forcefully articulated in a speech delivered a few months after he left the presidency. See REVELEY, supra note 15, at 254-56 (excerpting Ford's April 1977 speech). Referring to the practice of his presidency with respect to the War Powers Resolution, Ford stated that he had not believed that the War Powers Resolution was legally applicable in the instances that arose in his tenure. He stated, "Furthermore, I did not concede that the resolution itself was legally binding on the President on constitutional grounds." Id. at 254. See also MiChaEl J. GlennON, CONSTITUTIONAL DiplomaCy 93-96 (1990).

17. See 50 U.S.C. $\S 1543$ (1973).

18. See id. § 1544 .

19. See id.

20. For a discussion of reporting practices in the first decade under the Resolution, see Michael J. Glennon, The War Powers Resolution Ten Years Later: More Politics Than Law, 78 AM. J. INT'L L. 571 (1984).

21. For a discussion of the war powers record of the Carter Administration, see REVELEY, supra note 15 , at $257-61$.

22. 50 U.S.C. $\$ 1542$ (1973); see Lloyd Cutler, Counsel to President Carter, Legal Opinion on War Powers Consultation Relative to the Iran Rescue Mission, May 9, 1980, reprinted in Subcomm. on Int'l Sec. \& Scientific Affs. of the House Comm. on For. Affs., War Powers Resolution: Relevant Documents, Correspondence, Reports, 98th Cong., 1st Sess. 50 (1983). As the Cutler opinion observed, the consultation requirement comes into play only in the event of "hostilities" or "imminent hostilities," whereas the rescue mission was aborted before any such events. Id. 
During the Iran hostage crisis, the Office of Legal Counsel in the Justice Department addressed a variety of questions respecting potential uses of force in the Persian Gulf region and in general affirmed a wide scope of independent presidential authority to undertake the sorts of military operations then under contemplation. ${ }^{23}$ The opinion concluded that the War Powers Resolution "has neither the purpose nor the effect of modifying the President's [constitutional] power" in the circumstances envisaged, although constitutional issues could arise in the event of purported termination of an exercise of presidential power either by concurrent resolution or by lapse of time. ${ }^{24}$ Consistent with the position taken in President Nixon's veto message (and later endorsed by the Supreme Court in Immigration \& Naturalization Service v. Chadha ${ }^{25}$ ), the opinion argued that Congress could not require the removal of armed forces by means of a mere concurrent resolution. Yet it apparently acknowledged that Congress could control the duration of troop commitments through legislation that the President would have an opportunity to veto. ${ }^{26}$ In a notable divergence from the positions of Presidents Nixon and Ford, who believed that the arbitrary timetables of the Resolution could not constitutionally compel termination of an otherwise permissible presidential use of force, the opinion found sufficient flexibility in the Resolution's scheme to safeguard the President's constitutional authority:

We believe that Congress may, as a general constitutional matter, place a 60-day limit on the use of our armed forces as required by the provisions of $\S 1544$ (b) of the Resolution. The Resolution gives the President the flexibility to extend that deadline for up to 30 days in cases of ["] unavoidable military necessity.["] This flexibility is, we believe, sufficient under any scenarios we can hypothesize to preserve his constitutional function as Commander-in-Chief. The practical effect of the 60-day limit is to shift the burden to the President to convince the Congress of the continuing need for the use of our armed forces abroad. We cannot say that placing that burden on the President unconstitutionally intrudes upon his executive powers. ${ }^{27}$

It has been observed that this concession of congressional power to regulate presidential authority by statute "probably has not been uniformly admitted by the executive branch" and that it should not be assumed to represent the views of other administrations. ${ }^{28}$

23. See John M. Harmon, Assistant Attorney General, Office of Legal Counsel, Presidential Power to Use the Armed Forces Abroad Without Statutory Authorization, 4A Op. Off. Legal Counsel 185 (1980) [hereinafter Harmon Opinion].

24. Id. at $185,197$.

25. 462 U.S. 919 (1983). Chadha did not deal directly with war powers. Some commentators (e.g., ELY, supra note 13, at 119-20, 231) have contended that the legislative veto feature of the War Powers Resolution is arguably distinguishable from what the Supreme Court struck down in Chadha and might be constitutional. Most have assumed, however, that the formalistic logic of Chadha requires invalidating any measure by which Congress purports to require an action (in the case of the War Powers Resolution, removal of troops from hostilities) by means short of bicameral approval and presentment to the President.

26. See Harmon Opinion, supra note 23, at 186 (stating that "[w]e believe that Congress may terminate presidentially initiated hostilities through the enactment of legislation, but that it cannot do so by means of a legislative veto device such as a concurrent resolution").

27. Id. at 196.

28. See H. JefFerson Powell, The Constitution And the Attorneys General 411 (1999). 
President Reagan never conceded the applicability nor the constitutionality of the War Powers Resolution, yet his Administration did file a series of reports "consistent with the .. Resolution." 29 In 1983, Reagan signed the Multinational Force in Lebanon Resolution, ${ }^{30}$ with a statement saying that

I do not and cannot cede any of the authority vested in me under the Constitution as President and as Commander in Chief of the United States Armed Forces. Nor should my signing be viewed as any acknowledgment that the President's constitutional authority can be impermissibly infringed by statute. ${ }^{31}$

The Reagan Administration likewise vigorously contested the justiciability of several lawsuits brought by members of Congress to test the constitutionality of presidential uses of force and to enforce compliance with the War Powers Resolution and other congressional enactments in relation to the covert war in Central America, the intervention in Grenada, and the naval phase of the IranIraq war. ${ }^{32}$

President Bush's attitude is best encapsulated in what has become one of the most-quoted quips of the war powers literature: "I didn't have to get permission from some old goat in the United States Congress to kick Saddam Hussein out of Kuwait." ${ }^{33}$ Yet Bush did yield to congressional pressure to submit the question of initiation of hostilities against Iraq for congressional deliberation and vote. This submission resulted in the adoption of the Authorization for Use of Military Force Against Iraq Resolution on the eve of the outbreak of combat in January $1991 .{ }^{34}$ He also reported to the Congress "consistent with the War Powers Resolution" concerning the 1989 invasion of Panama and the 1992

29. See generally Glennon, supra note 20.

30. Pub. L. No. 98-119, 97 Stat. 805 (1983).

31. Statement of President Reagan Upon Signing Multinational Force in Lebanon Resolution, 19 WEEKLY COMP. PRES. DOC. 1442 (Oct. 12, 1983).

32. See Crockett v. Reagan, 558 F. Supp. 893 (D.D.C. 1982), aff'd, 720 F.2d 1355 (D.C. Cir. 1983), cert. denied, 467 U.S. 1251 (1984); Sanchez-Espinoza v. Reagan, 568 F. Supp. 596 (D.D.C. 1983), aff'd, 770 F.2d 202 (D.C. Cir. 1985); Conyers v. Reagan, 578 F. Supp. 324 (D.D.C. 1984), dismissed as moot, 765 F.2d 1124 (D.C. Cir. 1985); Lowry v. Reagan, 676 F. Supp. 333 (D.D.C. 1987), aff'd (No. 87-5426, D.C. Cir. 1988). Each of these cases was dismissed on one or another threshold ground (standing, mootness, political question, equitable discretion) without reaching the merits of the war powers questions.

33. 28 WeEKLY COMP. PRES. Doc. 1119 (June 20, 1992); see also Jane E. Stromseth, Rethinking War Powers: Congress, the President, and the United Nations, 81 GEO. L.J. 597, 655 (1993) (discussing the Bush statement).

34. Pub. L. No. 102-1, 105 Stat. 3 (1991) (codified as amended at 50 U.S.C. $\$ 1541$ (1994)) [hereinafter Iraq Resolution]. In signing the Iraq Resolution, President Bush expressed the "old goat" notion in the kind of prose that only lawyers can draft:

$[\mathrm{M}] \mathrm{y}$ request for congressional support did not, and my signing this resolution does not, constitute any change in the long-standing positions of the executive branch on either the President's constitutional authority to use the Armed Forces to defend vital U.S. interests or the constitutionality of the War Powers Resolution. I am pleased, however, that differences on these issues between the President and many in the Congress have not prevented us from uniting in a common objective.

Statement on Signing the Resolution Authorizing the Use of Military Force Against Iraq, 27 WEEKLY COMP. PRES. DOC. 48 (Jan. 14, 1991). 
deployment to Somalia. ${ }^{35}$ An opinion of the Office of Legal Counsel about the Somalia operation found no significant concerns about the War Powers Resolution because the troops were not expected to be involved in combat. ${ }^{36}$

The record from the Nixon Administration up to the onset of the Clinton Administration can thus be summarized as follows: No President explicitly conceded that Congress has a constitutional entitlement to share in the decision to introduce troops into hostilities; no president conceded that Congress could constitutionally control the Commander-in-Chief in the exercise of his Article II powers; yet patterns of compliance with the War Powers Resolution did emerge that are suggestive of an unwillingness to force differences of principle to a concrete confrontation.

III

\section{The Clinton Administration AND WAR POWERS}

The Clinton Administration has followed basically in this tradition, with some nuances. One could suggest two different interpretations of the Clinton record. Under the first interpretation, the Clinton Administration has acted essentially like its predecessors by preserving a broad view of executive power on the plane of principle, and likewise by refraining from pressing matters to a confrontation. President Clinton thus maintained continuity with previous administrations by asserting shortly before the September 1994 operation in Haiti that "[1]ike my predecessors of both parties, I have not agreed that I was constitutionally mandated to get" congressional approval for a military action of the sort contemplated in Haiti. ${ }^{37}$ Under an alternative interpretation, the Clinton Administration has arguably been more forthcoming than most predecessor administrations in issuing formal legal opinions suggestive of some constitutionally-based role for Congress, at least where "war' in the constitutional sense" is

35. For details on presidential reporting concerning Panama and other operations, see Ellen C. Collier, War Powers Resolution: Presidential Compliance (Cong. Research Service Issue Brief, Dec. 18, 1990). Presidential and congressional action concerning Somalia after President Clinton took office are discussed infra, text at note 43.

36. See Authority to Use United States Military Forces in Somalia, 16 Op. Off. Legal Counsel 8 (1992). In addition to concluding that the President had ample independent constitutional authority for a humanitarian use of U.S. troops, the opinion inferred tacit congressional approval from a sense-ofthe-Congress measure supportive of efforts to assure delivery of food and other relief. See id. at 13 (citing Horn of Africa Recovery and Food Security Act, Pub. L. No. 102-274, 106 Stat. 115 (1992)). The opinion also contended that the U.N. Security Council's endorsement of the operation could enhance presidential authority:

The President is entitled to rely on [Security Council Resolution 794, Dec. 3, 1992] .. in making his determination that the interests of the United States justify providing the military assistance that Resolution 794 calls for. Moreover, American assistance in giving effect to this and other Security Council resolutions pertaining to Somalia would in itself strengthen the prestige, credibility and effectiveness of the United Nations-which the President can legitimately find to be a substantial national foreign policy objective, and which will tend further to guarantee the lives and property of Americans abroad.

Id. at 12 .

37. Presidential News Conf., N.Y. TIMES, Aug. 4, 1994, at A16; see also Clinton Has Authority He Needs to Invade Haiti, Top Aides Say, N.Y. TimES, Sept. 12, 1994, at A1. 
involved. ${ }^{38}$ The following discussion traces the Clinton Administration's legal position through several important military engagements during the last seven years.

\section{A. Iraq}

Continuing the policy directions set by his predecessor, President Clinton has recurrently applied military force against Iraq throughout his Administration. Early in his presidency, President Clinton used cruise missiles against Baghdad in response to a foiled assassination attempt against ex-President Bush during his visit to Kuwait in early $1993 .^{39}$ On December 16, 1998, on the eve of his impeachment by the House of Representatives, President Clinton launched another round of cruise missiles against Iraq, in response to Iraq's repudiation of the U.N. regime for supervising elimination of weapons of mass destruction. ${ }^{40}$ One plausible legal basis for these actions (and various other actions throughout his presidency) could be the Iraq Resolution of January 14, 1991, which by its terms conferred open-ended authority on the President to use U.S. armed forces to achieve implementation of a series of U.N. Security Council resolutions, the last of which authorized U.N. member states not only to assist in ejecting Iraq from Kuwait but also "to restore international peace and security in the region." ${ }^{41}$ As required by the Iraq Resolution, the Administration has periodically reported to Congress on its efforts to achieve compliance with the Security Council resolutions. ${ }^{42}$ The legislative branch has evidently accepted (or at least has taken no steps at odds with) the executive claim of sufficient authority to deal forcibly with Iraq throughout the 1990s.

\section{B. Somalia}

The conflict in Somalia was also inherited from the previous administration. As one of the last major decisions of his presidency, taken in December 1992,

38. See Walter Dellinger, Assistant Attorney General, Deployment of United States Armed Forces into Haiti, 18 Op. Off. Legal Counsel 34 (1994) [hereinafter Dellinger Opinion] (implying a predecisional role for Congress in cases of "war' in the constitutional sense"). For discussion see infra, text at notes 51-54. The Harmon Opinion in the Carter Administration is the reason that the sentence in the text refers to "most" rather than "all" previous administrations.

39. See Letter to Congressional Leaders on the Strike on Iraqi Intelligence Headquarters, 29 WEEKLY COMP. PRES. DOCS. 1183 (June 28, 1993).

40. See Impeachment Vote in House Delayed as Clinton Launches Iraq Air Strike, Citing Military Need to Move Swiftly, N.Y. TIMES, Dec. 17, 1998, at A1. For background and references to President Clinton's addresses to the nation announcing the commencement and completion of the air strikes, see Sean D. Murphy, Contemporary Practice of the United States Relating to International Law, 93 AM. J. INT'L L. 470, 471-79 (1999).

41. Iraq Resolution, preamble ( $₫ 6), \S 2(a)$. For differing views on the scope of authority available to member states under the Security Council resolutions in question, compare Jules Lobel \& Michael Ratner, Bypassing the Security Council: Ambiguous Authorizations to Use Force, Ceasefires and the Iraqi Inspection Regime, 93 AM. J. INT'L L. 124 (1999), with Ruth Wedgwood, The Enforcement of Security Council Resolution 687: The Threat of Force Against Iraq's Weapons of Mass Destruction, 92 AM. J. INT'L L. 724 (1998).

42. Section 3 of the Resolution requires such reports to be submitted at least every 60 days. See Pub. L. No. 102-1, 105 Stat. 4 (1991). 
President Bush sent troops to Somalia for humanitarian reasons, with only the most slender reed on which to hang an inference of congressional approval. ${ }^{43}$ When the new Congress convened in early 1993, the Senate shortly passed one version of an authorizing resolution by voice vote ${ }^{44}$ but by the time the House took up the measure a few months later, the objectives of the mission had shifted in controversial directions. ${ }^{45}$ The House eventually passed an amendment that would have authorized military action with limitations as to both purpose and duration, but the Senate and the House never reconciled these differences. ${ }^{46}$ American troops were still in Somalia in October 1993, having undergone even more significant "mission creep" without the benefit of specific congressional authorization or much attention from the public, until the tragic day when eighteen Army Rangers lost their lives in an armed confrontation with one of the Somali factions. ${ }^{47}$ Congress soon mobilized itself to pass a measure cutting off funding for the deployment in Somalia as of March 31, 1994. ${ }^{48}$ President Clinton, however, had already made a preemptive announcement of his intention to withdraw the troops by that date, so he could hardly complain that Congress acted unconstitutionally in exercising its power of the purse to the same effect. ${ }^{49}$ The troops were indeed withdrawn by the cut-off date. Later, in reaction to the Somalia experience, Congress imposed new reporting and consultation requirements for prospective U.S. involvement in U.N. peacekeeping operations. ${ }^{50}$

C. Haiti

The Haitian operation was the first occasion for a reasonably full-scale articulation of the Clinton Administration's legal position on war powers. Walter Dellinger, then Assistant Attorney General for the Office of Legal Counsel, wrote a reasoned analysis of relevant constitutional and statutory questions just

43. As noted above, the Justice Department pointed to some earlier statutory language supportive of relief efforts in Somalia as suggesting tacit congressional authorization for a military operation in aid of humanitarian endeavors. Congress had gone out of session at the time that President Bush acted to dispatch troops. See supra note 36 and accompanying text.

44. S.J. Res. 45 (passed the Senate Feb. 4, 1993).

45. For details of the controversy and its outcome, see Jane E. Stromseth, Collective Force and Constitutional Responsibility: War Powers in the Post-Cold War Era, 50 U. MIAMI L. REV. 145, 168-72 (1995).

46. See id. at 169-70.

47. See John L. Hirsch \& Robert B. OAKley, Somalia and Operation Restore Hope: REFLECTIONS ON PEACEMAKING AND PEACEKEEPING 127-29 (1995).

48. See Pub. L. No. 103-139, § 8151, 107 Stat. 1418, 1475 (1993). The measure takes note that the original mission had received unanimous support from the Senate in S.J. Res. 45 passed February 4, 1993, and had been endorsed by the House in its amendment to S.J. Res. 45 of May 25, 1993. The limitation on funding the mission past March 31, 1994 contained the further proviso that "United States combat forces in Somalia shall be under the command and control of United States commanders under the ultimate direction of the President of the United States.” Pub. L. No. 103-139, § 8151(b)(2)(B), 107 Stat. 1418, 1476.

49. See Stromseth, supra note 45, at 171-72.

50. See Foreign Relations Authorization Act, Pub. L. No. 103-236, § 407, 108 Stat. 448-49 (1994) (codified at 22 U.S.C. $\S 287 b-4$ ). 
as U.S. troops were departing for what turned out to be a negotiated resolution of the crisis rather than a bloody invasion. ${ }^{51}$ The Dellinger opinion is one of the more reflective essays on the War Powers Resolution to emanate from the executive branch in twenty-five years. Rather than asserting insuperable constitutional defects in the War Powers Resolution, the opinion argues for an interpretation that would avoid or minimize the area of constitutional dispute, by construing the Resolution to presuppose a sphere in which Congress expected that the President would be able to act on his own authority to introduce U.S. armed forces into low-level hostilities of relatively brief duration. Although I have written elsewhere that another construction may make more sense of what Congress actually did in the Resolution than the construction proffered in the Dellinger opinion, ${ }^{52}$ the opinion in my view

marks a notable and welcome departure from the attitudes of prior administrations. In particular, it seems to accept that, for as long as the War Powers Resolution remains on the books, that resolution is indeed part of the operative corpus of law and is to be taken seriously. Moreover, the Dellinger letter also appears to proceed from the assumption that, in cases of initiation of major conflict, Congress would be constitutionally required to participate. ${ }^{53}$

In other words, the Clinton Administration's point of view does seem somewhat closer to the spirit of the Constitution as understood by the Congress in enacting the War Powers Resolution than to the attitudes of previous administrations. $^{54}$ Even so, the Clinton Administration maneuvered to avoid having the Haiti question come to a vote in advance of the threatened invasion. Congress later registered its disagreement with this tactic by declaring that "the President should have sought and welcomed [c]ongressional approval before deploying United States Armed Forces to Haiti. ${ }^{55}$

51. Dellinger Opinion, supra note 38.

52. See Lori Fisler Damrosch, The Constitutional Responsibility of Congress for Military Engagements, 89 AM. J. INT'L L. 58 (1995) [hereinafter Damrosch, Constitutional Responsibility] (contending that 60-90 day period does not presuppose independent presidential authority for short-term initiation of hostilities, but rather sets a timetable for congressional action when hostilities are initiated against U.S. armed forces deployed abroad). For Dellinger's response to my argument, see Walter Dellinger, After the Cold War: Presidential Power and the Use of Military Force, 50 U. MIAMI L. REV. 107, 116-117 (1995) (disagreeing on the interpretation of the statutory term "introduced . . into hostilities"). In this regard, Dellinger follows the Harmon Opinion, which likewise had considered that "introduction" should require "an active decision to place forces in a hostile situation rather than their simply acting in self-defense." Harmon Opinion, supra note 23, at 194 (noting that the Senate bill, in contrast to the War Powers Resolution as ultimately enacted, would have applied whenever forces are "engaged" in hostilities).

53. Damrosch, Constitutional Responsibility, supra note 52, at 60 . On the treatment of the concept of " war' in the constitutional sense" in the Dellinger Opinion, see id. at 65-67.

54. Significantly, the Dellinger Opinion did not invoke any claim that U.N. approval of a military action in Haiti had somehow augmented the President's constitutional powers. See id. at 67. By contrast, in respect of both the Iraq-Kuwait crisis and the Somalia interventions, the Bush Administration (like the Truman Administration in the Korean conflict) had referred to U.N. Security Council resolutions as arguably relevant to the scope of presidential authority to apply military force. See supra note 36.

55. Pub. L. No. 103-423 § 1, 108 Stat. 4358 (1994) (expressing the sense of the Congress). 


\section{Bosnia-Herzegovina}

The Clinton Administration did not directly acknowledge any requirement under the Constitution or the War Powers Resolution to submit the issue of military operations in former Yugoslavia for congressional approval. Before the deployment of ground troops to Bosnia-Herzegovina in implementation of the Dayton Agreement, ${ }^{56}$ U.S. military power had already been applied in the Balkan theater. U.S. vessels participated in interdiction operations in the Adriatic Sea in enforcement of the U.N. embargo, and U.S. air power policed the no-flight zone over Bosnia-Herzegovina and "safe havens" in Bosnian territory, and mounted air strikes against Bosnian Serb positions after the Srebrenica massacre. ${ }^{57}$

As part of the Dayton negotiations, President Clinton committed some 20,000 U.S. troops to the NATO Implementation Force in Bosnia-Herzegovina. Although preserving his position that congressional authorization was not constitutionally required, ${ }^{58}$ President Clinton stated that he would "welcome" an appropriate expression of congressional support. ${ }^{59}$ What transpired in the Congress was murkier than the President would have preferred. Shortly before the President left for the formal signing of the Dayton Agreement in Paris, Senate Majority Leader Bob Dole obtained a favorable vote in the Senate on a resolution expressing that body's "unequivocal[] support[]" for the troops to be sent to Bosnia but "reservations" about the presidential decision to dispatch them. ${ }^{60}$ The best that could be wheedled out of the House of Representatives was a backhanded statement of "pride and admiration" for the troops but "serious concerns and opposition to the President's policy." chambers had voted down proposals that would have restricted funds for the deployment. ${ }^{62}$ As Professor Stromseth has concluded, "[i]n the end, Congress as a body opted neither to block the deployment of American combat forces to Bosnia nor to authorize it." ${ }^{63}$

56. See Bosnia and Herzegovina-Croatia-Yugoslavia: General Framework Agreement for Peace in Bosnia and Herzegovina with Annexes, Dec. 14, 1995, 35 InT'L LEgAl MAT. 75 (1996), and Annex 1A, Agreement on the Military Aspects of the Peace Settlement, 35 INT'L LEGAL MAT. 92 (1996).

57. For the view that Congress implicitly accepted the kinds of military activities in Bosnia that were already underway in 1993, see Jane E. Stromseth, Understanding Constitutional War Powers Today: Why Methodology Matters, 106 YALE L.J. 845 (1996) (citing Department of Defense Appropriations Act, 1994, Pub. L. No. 103-139, § 8146, 107 Stat. 1418, 1474 (1993)).

58. I concur with this constitutional position, on the ground that the troops were not expected to become involved in hostilities. See also id. at 904.

59. See Letter to Senate Democratic Leader Thomas Daschle on Implementation of the Balkan Peace Process, 31 WeEKLY COMP. PRES. DoC. 2177 (Dec. 1, 1995).

60. S.J. Res. 44, 141 Cong. Rec. S18552 (Dec. 13, 1995).

61. H.R.J. Res. 302, 141 Cong. Rec. H14849 (Dec. 13, 1995).

62. See Stromseth, supra note 57, at 903-04. The Senate rejected a proposal (previously passed by the House) to limit funds for the Bosnian deployment; then the House narrowly defeated another proposed funding restriction.

63. See id. at 904. For a detailed account of presidential-congressional interactions over the Bosnia deployment, see Charles Tiefer, War Decisions in the Late 1990s by Partial Congressional Declaration, 36 San Diego L. Rev. 1, 9-16 (1999). See also Louis Fisher, Congressional Abdication: War and Spend- 
Meanwhile, the President and congressional leaders negotiated a budgetary compromise that included funding for the Bosnian deployment. But achieving agreement on other outstanding issues tied up in the budget negotiations proved elusive. President Clinton vetoed the authorizing legislation for defense expenditures that Congress passed in late December $1995 .{ }^{64}$ One of the reasons cited for the veto was a provision that would have attached a certification requirement to presidential decisions to place U.S. armed forces under the operational or tactical control of the United Nations, which Clinton characterized as an infringement on his constitutional authority as commander in chief. ${ }^{65}$ The House failed to override the veto. ${ }^{6}$ Later, Assistant Attorney General Walter Dellinger supplied a legal memorandum detailing the Administration's views on the unconstitutionality of such restrictions on presidential authority:

It is for the President alone, as Commander-in-Chief, to make the choice of the particular personnel who are to exercise operational and tactical command functions over the U.S. Armed Forces. ... In the present context, the President may determine that the purposes of a particular U.N. operation in which U.S. Armed Forces participate would be best served if those forces were placed under the operational or tactical control of an agent of the U.N., as well as under a U.N. senior military commander who was a foreign national (or U.S. national who is not an active duty military officer). Congress may not prevent the President from acting on such a military judgment concerning the choice of the commanders under whom the U.S. forces engaged in the mission are to serve. ${ }^{67}$

The memorandum is broadly consistent with legal positions of previous administrations that have interpreted the Commander in Chief Clause as establishing a sphere of presidential command authority into which Congress may not intrude. ${ }^{68}$

\section{E. Sudan and Afghanistan}

In August 1998, President Clinton ordered cruise missile attacks against a pharmaceutical plant in Sudan that was alleged to be a chemical weapons facility and against sites in Afghanistan identified as terrorist training camps. ${ }^{69}$ The rationale for the attacks was intelligence information indicating that the sites were part of a terrorist network connected with Usama bin Laden, who was al-

ing Powers, 43 ST. LOUIS U. L.J. 931, 972-976 (1999) (noting Congress's failure to grant affirmative authorization for military activities in Bosnia).

64. See National Defense Authorization Act for Fiscal Year 1996, H.R. 1530, 104th Cong. (1995).

65. See 142 Cong. Rec. H12 (daily ed. Jan. 3, 1996).

66. See id. at H22. The vote was 240 in favor of an override, 156 against, and 38 not voting. See Committee on Military Affairs and Justice of The Association of the Bar of the City of New York, Congressional Control of the Military in a Multilateral Context: A Constitutional Analysis of Congress's Power to Restrict the President's Authority to Place United States Armed Forces under Foreign Commanders in United Nations Peace Operations, 162 MIL. L. REV. 50, 63 (1999).

67. Memorandum on H.R. 3308 from Walter Dellinger, Assistant Attorney General, May 8, 1996, reprinted in 142 Cong. Rec. H10061-62 (daily ed. Sept. 5, 1996).

68. See, e.g., 41 Op. Att'y Gen. 291, $292-93$ (1956) (stating that Attorney General Rankin advised President Eisenhower on limits of congressional authority to impose restrictions on appointment of military personnel to positions of command responsibility); see also Committee on Military Affairs and Justice, supra note 66.

69. For a narrative of these and related events, see Murphy, supra note 40, at 161-67. 
leged to be the sponsor of the bombings of the U.S. embassies in Kenya and Tanzania that had taken place earlier the same month. ${ }^{70}$ The President's letter to congressional leaders, comparable to those of his predecessors concerning counterterrorist actions, recites, "I directed these actions pursuant to my constitutional authority to conduct U.S. foreign relations and as Commander in Chief and Chief Executive."

\section{F. Kosovo}

On March 24, 1999, NATO airstrikes began against the Federal Republic of Yugoslavia (Serbia and Montenegro) in an effort to interrupt the brutal campaign of "ethnic cleansing" being waged by Serb forces against the Kosovar Albanians. $^{72}$ This was a far more substantial use of military force than in previous deployments (Somalia, Haiti, Bosnia-Herzegovina) that had at least initially been characterized as not intended to result in combat. In Kosovo, the combatant posture was undeniable, yet the Clinton Administration couched its formal submissions so as to avoid an explicit acknowledgment that either "hostilities" within the meaning of the War Powers Resolution or "war' in the constitutional sense" was involved.

In the first report filed "consistent with the War Powers Resolution" on March 26, 1999, and in another report in the first week in April, President Clinton recited that he had "taken into account the views and support expressed by the Congress" in concurrent resolutions and that he "appreciate[d] the [continued] support of the Congress in this action.", "13 Yet neither at the outbreak of the conflict nor subsequently did Congress enact a specific statutory authorization within the meaning of the War Powers Resolution. Indeed, the several votes taken before and during the conflict were highly ambiguous. After the House voted in late April on a series of separate and inconsistent measures, including to defeat by a tie vote a measure of symbolic support for the air strikes, a White House spokesman expressed understandable frustration in saying that the Administration would press on with the bombing campaign:

70. See id.

71. Letter to Congressional Leaders Reporting on Military Action Against Terrorist Sites in Afghanistan and Sudan, 34 WeEKLy CoMP. Pres. DoC. 1650 (Aug. 21, 1998). Compare President Reagan's Letter to the Speaker of the House and the President Pro Tempore of the Senate, 22 WEEKLY COMP. PRES. DoC. 499 (Apr. 16, 1986) (describing April 14, 1986 strikes against Libya as "directed against the Libyan terrorist infrastructure").

72. For a range of perspectives on the Kosovo conflict, see Kosovo AND THE CHALLENGE OF HUMANITARIAN INTERVENTION, supra note 6; see also Editorial Comments: NATO's Kosovo Intervention, 93 AM. J. INT'L L. 831-69 (1999).

73. Letter to Congressional Leaders Reporting on Airstrikes Against Serbian Targets in the Federal Republic of Yugoslavia, 35 WEEKLY COMP. PRES. DOCS. 527 (Mar. 26, 1999); 35 WeEKLY COMP. PRES. Docs. 602 (Apr. 7, 1999) (citing S. Con. Res. 21 and H. Con. Res. 42). On March 24, 1999, the House had passed, by a vote of 424-1, a measure stating that it "supports the members of the United States Armed Forces who are engaged in military operations against the Federal Republic of Yugoslavia and recognizes their professionalism, dedication, patriotism, and courage." H.R. Res. 130, 106th Cong. (1999). 
"The House today voted no on going forward, no on going back and they tied on standing still." ${ }^{, 74}$

At the same time, President Clinton tendered to the congressional leadership assurances that Congress would indeed be involved in any decision to introduce ground troops into hostilities:

[W] ere I to change my policy with regard to the introduction of ground forces, I can assure you that I would fully consult with the Congress. Indeed, without regard to our differing constitutional views on the use of force, I would ask for Congressional support before introducing U.S. ground forces into Kosovo into a nonpermissive environment. ${ }^{75}$

The statement fits the now-familiar pattern of preserving the executive position on the plane of principle while presenting an accommodating stance on the plane of practical politics.

\section{THE CLINTON ADMINISTRATION IN LITIGATION OVER WAR AND FOREIGN AFFAIRS}

In Campbell v. Clinton, certain members of Congress brought suit on claims grounded in the Constitution and the War Powers Resolution in an effort to obtain judicial vindication of their position that Congress was constitutionally and statutorily required to approve the participation of U.S. armed forces in the Kosovo conflict. ${ }^{76}$ The Clinton Administration followed the consistent practice of its predecessors in urging that legislative plaintiffs could not have standing to sue on constitutional or statutory claims, that the issues were not ripe for adjudication, and that the case should be considered barred under the political question doctrine or otherwise nonjusticiable. ${ }^{77}$ After recounting the several congressional votes taken in the midst of the Kosovo crisis, which had neither explicitly authorized nor blocked the continuation of the conflict, ${ }^{78}$ the court re-

74. Alison Mitchell, Deadlocked House Denies Support for Air Campaign, N.Y. TIMES, Apr. 29, 1999, at A1. "The House voted 249-180 to require the President to seek Congressional approval for ground forces." Id. It also rejected by vote of 2-427 a call for a formal declaration of war and by 139290 a call for an immediate withdrawal of all U.S. forces. See id. The votes were precipitated by the insistence of Representative Tom Campbell on invoking the procedural provisions of the War Powers Resolution. See id.

75. In Clinton's Words: Speak with a Single Voice, N.Y. TIMES, Apr. 29, 1999, at A14.

76. See Campbell v. Clinton, 52 F. Supp. 2d 34, 39 (D.D.C. 1999).

77. See id. Similar defenses were asserted mutatis mutandis in the war powers suits against President Reagan cited supra note 32, as well as in Dellums v. Bush, 752 F. Supp. 1141 (D.D.C. 1990); Ange v. Bush, 752 F. Supp. 509 (D.D.C. 1990); and Pietsch v. Bush, 755 F. Supp. 62 (E.D.N.Y. 1991) involving the Iraq conflict.

78. See Campbell, 52 F. Supp. $2 \mathrm{~d}$ at 43 . The district court cited the four votes taken in the House on April 28, 1999, supra note 74, and, in addition, the rejection by a 213-213 tie vote of a concurrent resolution passed by the Senate on March 23, 1999, which would have authorized the President to conduct military air operations and missile strikes, see Campbell, 52 F. Supp. $2 \mathrm{~d}$ at 38 as well as the passage on May 20, 1999 of an Emergency Supplemental Appropriations Act which included money for Kosovo operations but lacked the explicit recital necessary to constitute specific statutory authorization for purposes of the War Powers Resolution, see id. at 38-39. 
lied on Raines $v$. Byrd ${ }^{79}$ to conclude that congressional plaintiffs could not satisfy the standards laid down by the Supreme Court for standing to sue: Their alleged injury was too general, and the mixed messages from the various congressional actions had not produced a constitutional impasse. ${ }^{80}$ Within a few days of the district court's decision, active combat had ceased and U.S. armed forces were entering Kosovo in a noncombatant posture for implementation of the terms of settlement of the conflict. ${ }^{81}$

Though its litigating position in Campbell was predictable, the Clinton Administration has, in my opinion, gone too far in straining to avoid adjudication on the merits in foreign relations contexts. In Breard $v$. Greene, ${ }^{82}$ a death penalty case involving rights under a treaty of the United States ${ }^{83}$ the Administration essentially argued that there was no forum competent to provide a remedy for the conceded treaty violation. ${ }^{84}$ In the lower federal court, the statement of interest of the United States as amicus curiae argued that domestic courts should not take cognizance of the treaty claim. ${ }^{85}$ Along with a variety of threshold objections (including an expansive invocation of the political question doctrine), the government maintained that U.S. courts were foreclosed from hearing the case because the treaty itself provided for disputes under the treaty to be heard at the International Court of Justice (the "ICJ") in The Hague. "Yet when the aggrieved foreign state thereupon invoked this treaty right to sue in the ICJ, the United States urged that body to decline jurisdiction on the grounds (among others) that there was no genuine dispute between the parties and that the treaty claim had not been properly preserved in domestic courts. ${ }^{87}$ Then, when the ICJ entered an interim order calling on the United States to

79. 521 U.S. 811 (1997) (holding that the members of Congress did not have a sufficient personal stake in the dispute and had not alleged a sufficiently concrete injury to have established standing under Article III, and that the institutional injury that the members alleged was wholly abstract and widely dispersed).

80. See Campbell, 52 F. Supp. $2 \mathrm{~d}$ at 43.

81. See Letter to Congressional Leaders on the Deployment of United States Military Personnel as Part of the Kosovo International Security Force, 35 WEEKLY COMP. PRES. DOCS. 2484 (June 12, 1999); see also Letter to Congressional Leaders Reporting on the Deployment of Military Forces for Stabilization of Areas of the Former Yugoslavia, 35 WEEKLY COMP. PRES. DoCs. 1416 (July 19, 1999).

On May 25, 1999, approximately the sixtieth day of the conflict, another letter had also been sent to congressional leaders; but it was not in the form that would have been expected to obtain extension of the War Power Resolution's timetable from 60 to 90 days pursuant to $\S 5$ (b) of the Resolution, as that extension is supposed to be available only upon the President's certification that the troops are in the process of being withdrawn and that the extension is necessary for their safe withdrawal. See 35 WEEKLY COMP. PRES. DOCS. 989 (May 25, 1999).

82. 523 U.S. 371 (1998).

83. See Vienna Convention on Consular Relations, Apr. 24, 1963, 21 U.S.T. 77, 596 U.N.T.S. 261.

84. For a more detailed critique of the Administration's position, see Lori Fisler Damrosch, The Justiciability of Paraguay's Claim of Treaty Violation, 92 AM. J. INT'L L. 697 (1998).

85. See Brief for the United States as Amicus Curiae, Republic of Paraguay v. Allen, 134 F.3d 622 (4th Cir.), cert. denied sub nom. Breard v. Greene, 523 U.S. 371 (1998).

86. See id., at 2, 20, 24 (stating that foreign states' claims of treaty violations are properly resolved "through actions before appropriate international bodies"; disputes covered by the Vienna Convention should be brought to the ICJ rather than to domestic courts).

87. See Case Concerning the Vienna Convention on Consular Relations (Para. v. U.S.), Provisional Measures (Order of Apr. 9, 1998). 
"take all measures at its disposal" to ensure that Breard would not be executed, the Solicitor General declined to ask the U.S. Supreme Court to enter a stay of execution. ${ }^{88}$ In essence, the federal government's position was that the federal judiciary lacks power to give effect to a claim of right under a treaty, and that the remedy (if any) within our federal system would have to come from the Governor of Virginia ${ }^{89}$ - one of the more bizarre views of federalism ever to emanate from the federal executive branch! ${ }^{90}$

The Breard matter presents one variant of the issue raised in Professor Johnsen's paper ${ }^{91}$ concerning the responsibility of the President under the Take Care Clause. ${ }^{92}$ Are treaty obligations part of the "law of the land," ${ }^{93}$ and if so, what is the responsibility of the President to see that they are enforced? Professor Johnsen prefers an approach under which the executive branch would craft its position so that disputes are more likely to be heard on their merits in the Article III mode; she would presumably disfavor executive branch maneuverings to avoid a justiciable case or controversy. ${ }^{94}$ In my view (and that of many other commentators on Breard), ${ }^{95}$ the Clinton Administration abdicated its responsibility to ensure a fair adjudication of the merits of the claim of treaty violation.

$\mathrm{V}$

\section{CONCLUSION: A CLINTON DOCTRINE ON WAR POWERS?}

The Kosovo conflict has prompted some commentators to discern a "Clinton Doctrine" of humanitarian intervention, in the President's affirmation that he might well authorize a comparable response to future Kosovo-like situations if U.S. military power could help abate other humanitarian catastrophes. ${ }^{96}$ The Clinton Administration's constitutional doctrine on war powers, however, is only subtly different from that of its predecessors, in the sense of a slightly more deferential attitude toward the role of Congress under the governing framework legislation. A less confrontational stance may be motivated as much by politics as by principle, since this President can ill afford to antagonize Congress unnecessarily.

88. Brief for the United States as Amicus Curiae, Republic of Paraguay v. Gilmore and Breard v. Greene, 523 U.S. 371 (1998).

89. For excerpts from executive and judicial documents and scholarly commentary, see Jonathan I. Charney \& W. Michael Reisman, Agora: Breard, The Facts, 92 AM. J. INT'L L. 666, 667-712 (1998).

90. The symposium audience will be glad to know that Walter Dellinger had left the position of Acting Solicitor General and had returned to his professorship at Duke University School of Law before the filing of the amicus brief in Breard.

91. See Johnsen, supra note 9.

92. U.S. CONST. art. II.

93. Id., art. VI.

94. See generally Johnsen, supra note 9 .

95. See, e.g., the selection of commentary in Charney \& Reisman, supra note 89.

96. See, e.g., G. John Ikenberry, The Costs of Victory: American Power, Post-Cold War Order, and the Use of Force in Kosovo, in Kosovo AND THE CHALlenge OF HuMANitARIAN INTERVENTION, supra note 6. 
President Clinton has been no less able than his predecessors to carry out his military policies with only the mild irritant of occasionally having to ask the Congress to support, or to refrain from undercutting, executive decisions already taken. Perhaps some irony can be detected in the fact that the only two specific statutory authorizations adopted in strict accordance with the provisions of the War Powers Resolution happened during the tenures of President Reagan, for Lebanon, and President Bush, for Iraq. President Clinton has been more respectful of Congress's constitutional role than either of those two predecessors, yet less successful in persuading Congress to exercise the responsibility that goes along with the claim of constitutional power. ${ }^{97}$ But, as Professor Koh stated a decade ago, the bottom line remains: "The President almost always wins in foreign affairs." 98

97. Cf. ELY, supra note 13, at 47-67 (including a chapter on "inducing Congress to face up to its constitutional responsibilities").

98. Harold Hongju Koh, Why the President (Almost) Always Wins in Foreign Affairs: Lessons of the Iran-Contra Affair, 97 YALE L.J. 1255 (1988). 